Available online at GSC Online Press Directory

GSC Biological and Pharmaceutical Sciences

e-ISSN: 2581-3250, CODEN (USA): GBPSC2

Journal homepage: https://www.gsconlinepress.com/journals/gscbps

(RESEARCH ARTICLE)

\title{
Blood donation type and hepatitis B and C seroepidemiology at Hôpital Sominé DOLO de Mopti
}

\author{
Modibo Coulibaly ${ }^{1,}{ }^{*}$, Bakary Maiga ${ }^{2}$, Moussa Diawara ${ }^{1}$, Dramane Samaké ${ }^{3}$, Valentin Sagara ${ }^{1}$, Bréhima \\ Traoré 4 , Oumar Guindo ${ }^{4}$, Mounirou Baby ${ }^{2}$ and Amagana DOLO 2 \\ ${ }^{1}$ Centre National de Recherche Scientifique et Technologique, Biomedical laboratory, Hôpital Sominé DOLO de Mopti, Mopti, Mali. \\ 2 Université des Sciences Techniques et Technologiques de Bamako, Faculty of pharmacy, Bamako, Mali. \\ ${ }_{3}^{3}$ Centre National de Recherche Scientifique et Technologique, Medicine, Hôpital Sominé DOLO de Mopti, Mopti, Mali. \\ ${ }^{4}$ Centre National de Recherche Scientifique et Technologique, Public Health, Hôpital Sominé DOLO de Mopti, Mopti, Mali.
}

Publication history: Received on 20 November 2020; revised on 29 November 2020; accepted on 03 December 2020

Article DOI: https://doi.org/10.30574/gscbps.2020.13.3.0393

\begin{abstract}
Background: The increasing prevalence of hepatitis viral markers in developing countries results in a concern in the setting of blood transfusion safety. The aim of this study was to assess the prevalence of hepatitis viral markers among blood donors and their link with sociodemographic factors.

Methods: We performed a retrospective study on blood donors screened for HBV and HCV. HBV and HCV serologies were performed by immunochromatographic methods using Alere Determine ${ }^{\mathrm{TM}} \mathrm{HBs}-\mathrm{Ag}$ and SD BIOLOLINETM HCV-Ab. Data were analyzed by R 3.4.3. The logistic regression was fitted in univariate and multivariate analysis.

Results: A total of 11,372 donors were enrolled. The overall prevalence was $10.4 \%$. The specific prevalence of HBV and HCV were $8.9 \%$ and $1.5 \%$ respectively. The co-infection rate was $0.3 \%$. HBV seropositivity proportion was significantly higher in family donors compared to volunteer $(9.8 \%$ vs $6.0 \%$, or $=1.71[1.30-2.29] \mathrm{p}<0,001)$. HBV seropositivity was positively influenced by male sex aOR $=1.77$ [1.4-2.26], $\mathrm{p}<0.001$ and unemployed aOR $=1.20$ [1.03-1.40], $\mathrm{p}=0.02$ in multivariate analysis.
\end{abstract}

Conclusion: Our data suggest that voluntary donors and particularly female which had an occupation had a lower prevalence of hepatitis viral markers.

Keywords: Blood donation; Hepatitis; Seroepidemiology; Hôpital Sominé DOLO de Mopti.

\section{Background}

Hepatitis B and C virus are viral infections that spread in the liver and can result in chronic, cirrhosis and hepatocellular carcinoma disease. The virus are most commonly transmitted vertically from mother to child during birth and delivery, as well as horizontally through contact with blood or other body fluids including unsafe blood transfusion [1]. The World Health Organization (WHO) 2017 report estimated that 257 millions of people were living with chronic HBV infection, and 71 millions of people with chronic HCV infection in 2015. Hepatitis B prevalence is highest in the WHO African Region, where $6.1 \%$ of the adult population is infected [2]. The strategies adopted to lowering hepatitis prevalence include many efforts such as vaccination at birth for HBV, pregnant women and blood donors screening and treatment of cases for both HBV and HCV have paid a dividend [3]. However, these diseases still remain a major public health problem and scientific community must tighten their belts to decrease the burden of these diseases. Blood transfusion

\footnotetext{
* Corresponding author: Dr. Modibo Coulibaly

Centre National de Recherche Scientifique et Technologique, Biomedical laboratory, Hôpital Sominé DOLO de Mopti, Mopti, Mali. 
is not completely safe, data showed high prevalence of HBV and HCV in polytransfused patients such as patients with sickle cell disease [4]. Moreover, mathematical modeling of transfusion-transmitted viral infections (TTVI) have shown residual risks of infection in blood recipients [5-7].Therefore, WHO calls its state members to eliminate hepatitis B and $\mathrm{C}$ by reducing new infections up to $90 \%$ and decrease mortality by $65 \%$ by 2030 [2]. The objective of this study was to assess the prevalence of hepatitis B and C among blood donors and to highlight the association between HBV and HCV seropositivity and sociodemographic variables.

\section{Material and methods}

We performed a retrospective, descriptive and analytical study of blood donation from 2011 to 2014 at Hôpital Sominé DOLO de Mopti. This study covered all volunteer and family donors which were aged between 18 and 55, weighed at least 55 kilograms, healthy, good physical condition and able to donate blood. The samples were taken by venipuncture at the level of the fold of the elbow. Approximately $2 \times 2 \mathrm{ml}$ of blood were taken for each donor on a dry and EDTA blood collection tubes. Viral markers research was carried out by the immuno-chromatographic methods by using Alere Determine ${ }^{\mathrm{TM}} \mathrm{HBs}-\mathrm{Ag}$ and SD BIOLINETM $\mathrm{HCV}-\mathrm{Ab}$ on the sera obtained after centrifugation at $1500 \mathrm{G}$ for 5 minutes. We analyzed two dependent variables (HBV and HCV serological status), an independent variable (type of donation: volunteer donor or family donor) and co-variables made up of the sociodemographic status, occupational and study level. Data were recording in Microsoft Excel and analyzed by R i386 software version 3.3.4. The Pearson Chi2 test was used to compare the proportions with determination of the crude Odds Ratios (OR), their 95\% confidence interval (CI) and adjusted Odds Ratios (aOR) in multivariate analysis. The Wald Chi2 p-values were used in the final model for statistical significance.

\section{Results}

A total of 11, 372 donors were enrolled. The sex-ratio was 7.7. The age structure of donors was young one with an average of $32 \pm 9$ years. Blood donation was significantly familial than volunteer, $92.2 \%$ vs $7.76 \%$, p < 0.001. Donors was essentially of male sex, $88.3 \%$ for family donors and $90.8 \%$ for volunteer donors. We fund a significant difference between family and volunteer donors by sex, $\mathrm{p}=0.03$; occupation status, $\mathrm{p}<0.001$; study level, $\mathrm{p}=0.004$; and ethnicity $\mathrm{p}<0.001$ (Table 1). The overall prevalence of viral markers was $10.4 \%$. All of blood donors who were positive for one marker were referred to infectious diseases physician for case management. The specific prevalence of HBV and HCV were $8.9 \%$ and $1.5 \%$ respectively. The co-infection (HBV-HCV) rate was $0.3 \%$ (Figure 1 ). Univariate analysis show that HBV proportion of seropositivity was significantly higher in family donors compared to volunteer donors $9,8 \%$ vs $6,0 \%$, $\mathrm{OR}=1.71[1.30-2.29] \mathrm{p}<0,001$ (Figure $2 \mathrm{~A}$ ). We did not fund no difference between family donors and volunteer donors in term of HCV seropositivity $1.90 \%$ vs $1.58 \%$, , OR=1.20 [0.72-2.17], p = 0.6 (Figure 2 B). HBV seropositivity was positively influenced by male sex aOR 1.77 [1.4 - 2.26], $\mathrm{p}<0.001$ and unemployed aOR=1.20 [1.03- 1.40$], \mathrm{p}=0.02$ in multivariate analysis (Table 2). None of the sociodemographic factors studied had any impact on HCV seropositivity.

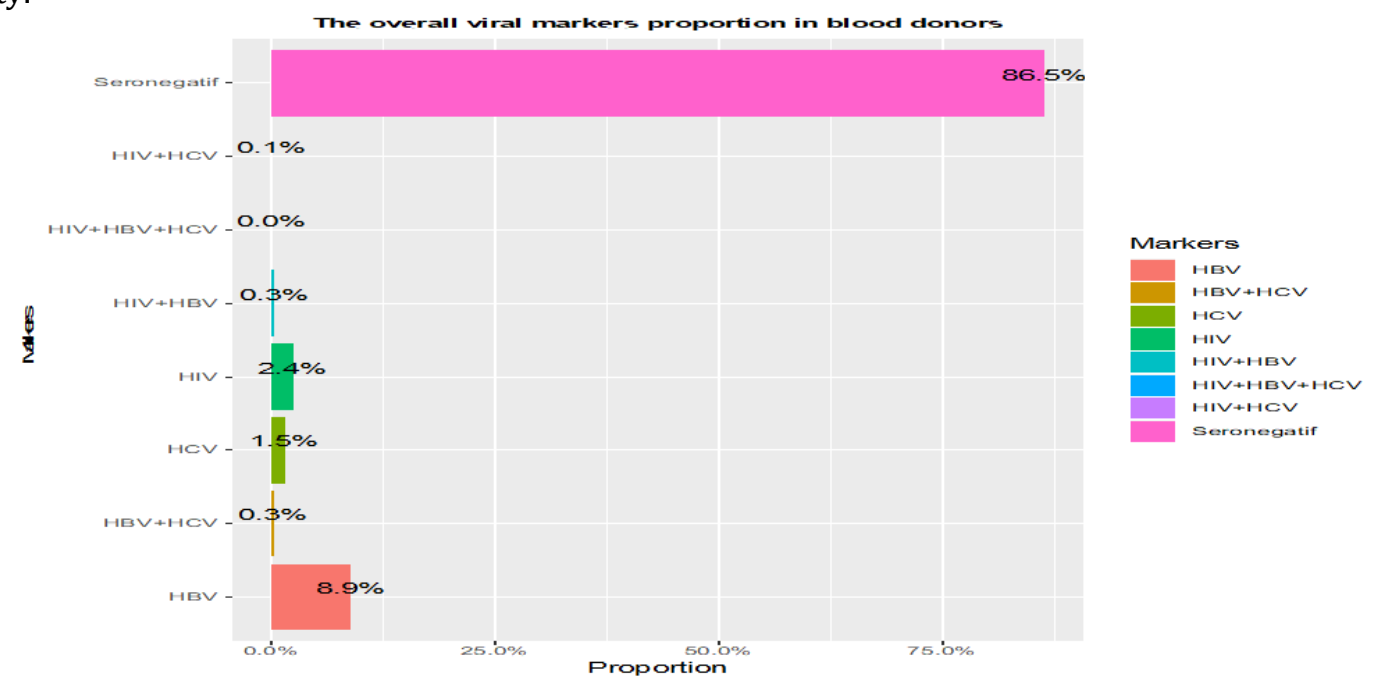

Figure 1 The overall prevalence of viral markers in blood donors.

HBV = Hepatitis B Virus, HCV = Hepatitis C Virus, HIV = Human Immunodeficiency Virus 

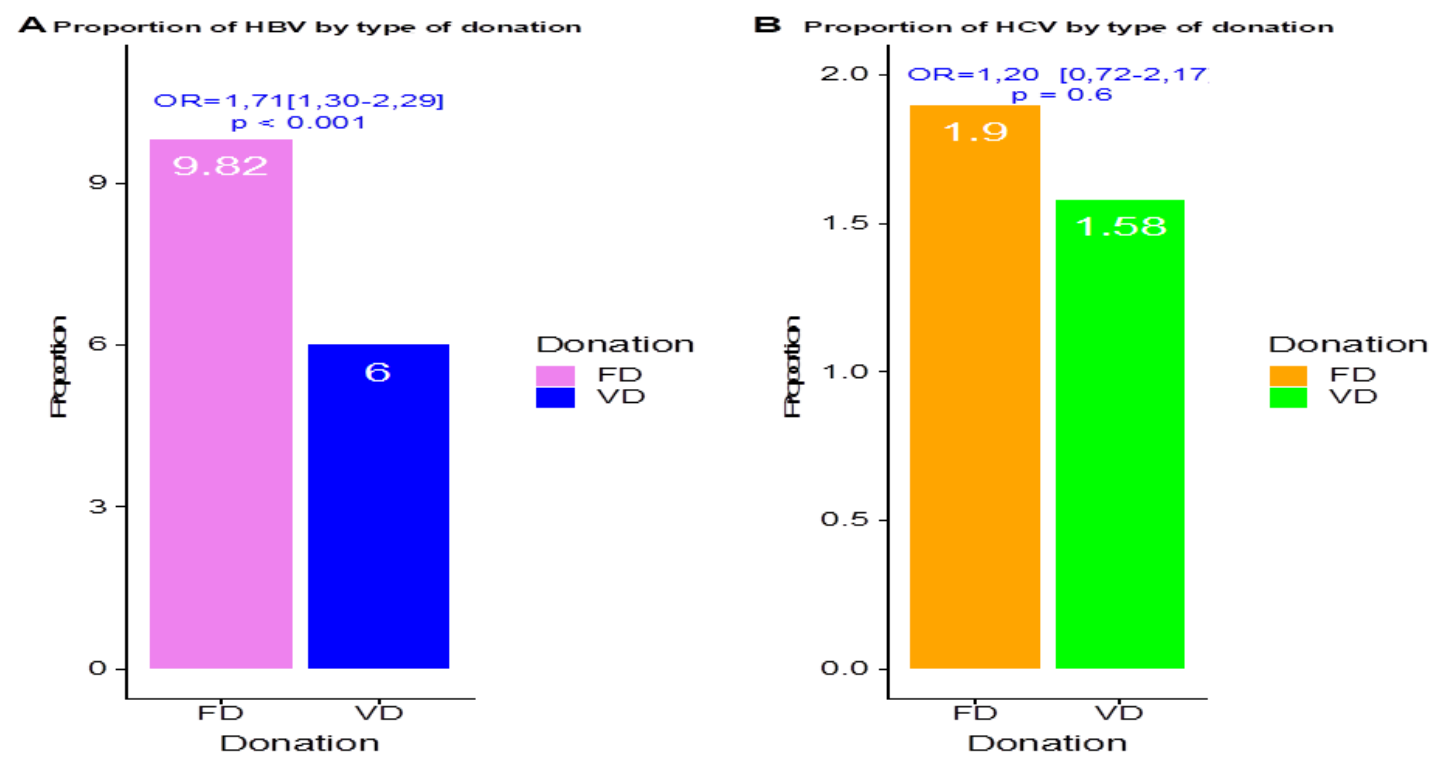

Figure 2 Association of hepatitis markers and blood donation type in univariate analysis. FD = Family Donors, VD = Volunteer Donors, OR = Odd Ratio.

Table 1 Sociodemographic characteristics of blood donor types.

\begin{tabular}{|l|l|l|l|}
\hline Variables & Family Donor & Volunteer Donor & p \\
\hline N & 10,489 & 883 & \\
Percentage & 92.24 & 7.76 & $<0.001$ \\
\hline Man (\%) & 88.35 & 90.83 & \\
Woman (\%) & 11.65 & 9.17 & 0.03 \\
\hline = 18 years (\%) & 1.6 & 0.9 & \\
{$[19-29$ years] (\%) } & 38.6 & 35.8 & \multirow{2}{*}{0.09} \\
{$[30-39$ years] (\%) } & 35.0 & 37.3 & \\
$\geq 40$ years (\%) & 24.8 & 26.0 & \\
\hline Mopti region (\%) & 97.32 & 98.19 & \\
Outside Mopti (\%) & 2.68 & 1.81 & \\
\hline With occupation (\%) & 46.9 & 59.5 & \\
Students (\%) & 9.0 & 7.7 & \\
Unemployed (\%) & 44.1 & 32.8 & \\
\hline Non-literate or primary education level (\%) & 74.6 & 70.0 & \\
Secondary education level (\%) & 18.1 & 20.2 & \\
High education level (\%) & 7.3 & 9.8 & \\
\hline Fulani & 22.8 & 20.1 & \\
Bozo & 17.4 & 16.6 & \\
Dogon & 19.1 & 15.7 & \\
Sonrhaï & 10.9 & 9.2 & \\
Bambara & 21.9 & 30.4 & \\
Others & 7.9 & 8.0 & \\
\hline
\end{tabular}


Table 2 Adjusted Odd Ratio (aOR) and 95\% CI, of the HBV serology result according to the type of blood donation in multivariate analysis.

\begin{tabular}{|c|c|c|c|c|c|}
\hline Variables & & $\mathbf{N}$ & aOR & & $\mathbf{p}$ \\
\hline \multirow[t]{2}{*}{ Donation } & FD & 10,482 & & Reference & \\
\hline & VD & 879 & & $0.69(0.44,0.77)$ & $<0.001$ \\
\hline \multirow[t]{2}{*}{ Sex } & Woman & 1,350 & & Reference & \\
\hline & Man & 10,056 & & $1.60(1.34,2.15)$ & -0.001 \\
\hline \multirow[t]{4}{*}{ Age classes } & [18 years] & 182 & & Reference & \\
\hline & [19-29 years] & 4,364 & & $1.22(0.73,2.17)$ & 0.48 \\
\hline & [30-39 years] & 3,996 & & $1.12(0.67,2.00)$ & 0.60 \\
\hline & {$[\geq 40$ years $]$} & 2,819 & & $0.96(0.57,1,72)$ & 0.88 \\
\hline \multirow[t]{6}{*}{ Ethinic } & Others & 899 & & Reference & \\
\hline & Bambara & 2,557 & & $1.15(0.88,1.52)$ & 0.32 \\
\hline & Bozo & 1,976 & & $1.33(1.01,1.76)$ & 0.05 \\
\hline & Dogon & 2,136 & & $1,40(1,07,1,80)$ & 0.01 \\
\hline & Fulani & 2,568 & & $1.05(0.80,1.39)$ & 0.75 \\
\hline & Sonrhai & 1,225 & & $1.13(0.84,1.54)$ & 0.43 \\
\hline (Intercept) & & & -5 & $0.05(0.03,0.09)$ & $=0.001$ \\
\hline
\end{tabular}

$\mathrm{N}=$ Number, $\mathrm{aOR}=$ adjusted Odd Ratio, FD = Familial Donors, $\mathrm{VD}=$ Volunteer Donor .

\section{Discussion}

Transfusion safety involves screening of viral markers in both family and volunteer donors. The difference of seroprevalence of these markers between family and volunteer donors has been the subject of much controversy [810]. However, it is generally accepted that regular volunteer donors have a lower seroprevalence compared to replacement or family ones [11-13]. In our study, family donors were significantly higher than volunteer donors $92.24 \%$ vs. $7.76 \% \mathrm{p}<0.001$. This data suggests that blood donation is still family-based in our hospital instead of volunteer donations which have been promoted by the World Health Organization [14-15]. However, Asenso-Mensah K and al., in 2014 and Allain JP and al., in 2016 by adjusting for age and sex showed that there was no difference in risk of transfusion transmitted infection between family and first time volunteers donors. They concluded that the exclusion of family donors would be illegitimate and harmful for the availability of the blood product in resource-limited countries [16-17]. We found a significant difference between family and volunteer donors in terms of sex $p=0.03$. Male sex was more likely to be blood donor than woman $88.35 \%$ vs $11.65 \%$. This could be explained by the existence of many contraindications to blood donation in woman than in man. Moreover, there were more male volunteers donor than family donors, and women were more likely to be in the family donor category than volunteer. These could be linked again to the many contraindications in women [18-19]. The distribution of donors in the two categories was significantly different for occupational status and level of education. More donors in the volunteer donor category were more likely to be workers. On the other hand, pupils, students and the unemployed were better represented in the family donor category $\mathrm{p}<0.001$. Non-literate and primary education level donors were more represented in the family donor category, while those with secondary and higher education levels were more represented in the volunteer donor category $\mathrm{p}=0.004$. These could be explained by the higher resilience of working donors and those with a secondary and higher education level compared to other donors. These findings are similar to studies conducted by Thompson WW and $a l$. , in the United States and Tavakol $\mathrm{N}$ and $a l$. , in Iran, who have shown the importance of education and professional status in the propensity to donate blood and even to becoming regular volunteer donors [20-21]. The overall seroprevalence in blood donors was $10.4 \%$. The specific prevalence of the hepatitis B virus surface antigen (HBs-Ag) and the hepatitis $\mathrm{C}$ virus antibody (HCV-Ab) were respectively $8.9 \%$, and $1.5 \%$. The co-infection HBV and HCV proportion was $0.3 \%$. Proportionally, our results are lower than those obtained by Diarra A and $a l, 2007$ at the National Center of Blood Transfusion of Bamako, who found a prevalence of $13.9 \%$ and 3.3\% respectively for $\mathrm{HBV}-\mathrm{Ag}$ and $\mathrm{HCV}$ $\mathrm{Ab}$ [22]. Moreover, Koné MC and al., 2012 have found relatively lower prevalences in donors at Hôpital Nianankoro Fomba of Ségou, ie 5.3\% and 0.5\% respectively for HBs-Ag and HCV-Ab [23]. The trend of high prevalence of viral 
markers in blood donors in developing countries such as ours has been reported in several studies in West and Central Africa. This is the case for Mayaki Z and al., 2013 in Niger, who found a prevalence of 15.5\%, and 1.2\% respectively for HBs-Ag and HCV-Ab among donors in Niamey [24]. Buseri FI and al., 2009 reported a prevalence of 18.1\% and 6.0\% respectively for HBs-Ag and HCV-Ab in Nigeria [25]. In Central Africa, Ankouane F and al., 2016, found a prevalence of $12.6 \%$ and 3.2\% respectively for HBs-Ag and HCV-Ab in Cameroon [26] while Nambei WS and al., 2016 found $8.9 \%$ and $4.72 \%$ respectively for HBs-Ag and HCV-Ab [11]. However, lower prevalences have been reported by Offergeld R and al., 2012 in Germany, Sommese L and al., 2014 in Italy and Sehgal S and al., 2017 in Island; showing thigh disparity in the prevalence of viral markers between rich, middle and low-income countries [27-29]. The distribution of viral markers was significantly different in the two donor groups. Indeed, univariate analysis revealed that the risk of having a positive viral marker was 1.71 times [CI $=1.30$ To 2.29], $\mathrm{p}<0.001$ for HBs-Ag in family donors than in volunteer donors. Many studies have shown higher seroprevalence of HBV-Ag among family donors than volunteers. This is the case for Mole S and al., in 2011 in Cameroon and Tounkara A and al., in Mali [30-31]. However, as Diarra A and al., we did not found difference of having positive HCV-Ab between family and volunteer donors $\mathrm{OR}=1.20$ [CI = 0.72 to 2.17 , $\mathrm{p}=0.6$ for. Multivariate analysis showed a positive association between male sex $\mathrm{aOR}=1.69$ [1.34-2.15], $\mathrm{p}<0.001$; Dogon ethnic aOR=1.40 [1.07-1.86], $\mathrm{p}=0.01$ and Bozo ethnic $\mathrm{aOR}=1.33$ [1.01-1.76], $\mathrm{p}=0.05$ and HBV-Ag seropositivity. Volunteer donors was negatively associated to HBV-Ag seropositivity aOR $=0.59$ [0.44-0.77], $\mathrm{p}<0.001$.

\section{Conclusion}

Our data suggest that female voluntary donors with secondary or higher education level had a low prevalence of viral markers. An incentive scheme of awareness should be conducted among low-educated and unemployed male blood donors to let them become a regular volunteer with a high level of resilience and low-risk behavior in order to reduce HBV-Ag and HCV-Ab seroprevalence in blood donors.

\section{Compliance with ethical standards}

\section{Acknowledgments}

We are grateful to all study subjects for participating in this study; the staff of Hôpital Sominé DOLO de Mopti, Department of Biomedical Laboratory, Mopti, Mali, Faculty of Pharmacy, Bamako, Mali, Centre de Recherche Scientifique et Technologique, Bamako, Mali, for developing the protocol and providing the research team and logistical support.

\section{Disclosure of conflict of interest}

Authors certify that there is no actual or potential conflict of interest in relation to this article. Funding for reagents and other medical devices comes from the Ministry of Health and is free from all sources of conflict of interest.

\section{Statement of informed consent}

Each participant gave fully informed written consent prior to enrollment. The protocol was reviewed and approved by the Faculty of Pharmacy and Hospital.

\section{References}

[1] Mysore KR, Leung DH. Hepatitis B and C. Clin Liver Dis. Nov 2018; 22(4): 703-722.

[2] World Health Organization. Global Hepatitis Report. 2017.

[3] Meryem Jefferies, Bisma Rauff, Harunor Rashid, Thao Lam, Shafquat Rafiq. Update on global epidemiology of viral hepatitis and preventive strategies. World J Clin Cases. 6 Nov 2018; 6(13): 589-599.

[4] Mehdi Nouraie, Sergei Nekhai, and Victor R Gordeuk. Sickle cell disease is associated with decreased HIV but higher HBV and HCV comorbidities in US hospital discharge records: a cross-sectional study. Sex Transm Infect. Nov 2012; 88(7): 528-533.

[5] Arzouma Paul Yooda, Salam Sawadogo, Serge Théophile Soubeiga, Dorcas Obiri-Yeboah, Koumpingnin Nebie, Abdoul Karim Ouattara, Birama Diarra and al. Residual risk of HIV, HCV, and HBV transmission by blood transfusion between 2015 and 2017 at the Regional Blood Transfusion Center of Ouagadougou, Burkina Faso. J Blood Med. 2019; 10: 53-58. 
[6] Claudio Velati, Luisa Romanò, Vanessa Piccinini, Giuseppe Marano, Liviana Catalano, Simonetta Pupella, Giuseppina Facco, Ilaria Pati, Maria Elena Tosti, Stefania Vaglio, Giuliano Grazzini, Alessandro Zanetti, Giancarlo M. Liumbruno. Prevalence, incidence and residual risk of transfusion-transmitted hepatitis $\mathrm{C}$ virus and human immunodeficiency virus after the implementation of nucleic acid testing in Italy: a 7-year (2009-2015) survey. Blood Transfus. Sep 2018; 16(5): 422-432.

[7] Moon Jung Kim, Quehn Park, Hyuk Ki Min, Hyun Ok Kim. Residual risk of transfusion-transmitted infection with human immunodeficiency virus, hepatitis C virus, and hepatitis B virus in Korea from 2000 through 2010. BMC Infect Dis. 2012; 12: 160.

[8] Allain JP, Sarkodie F, Asenso-Mensah K, Owusu-Ofori S. Relative safety of first-time volunteer and replacement donors in West Africa. Transfusion. Feb 2010; 50(2): 340-3.

[9] Allain JP. Moving on from voluntary non-remunerated donors: who is the best blood donor? Br J Haematol. Sep 2011; 154(6): 763-9.

[10] Ben Jemia R, Gouider E. Seroprevalency of transfusion-transmitted infections in first-time volunteer and replacement donors in Tunisia. Transfus Clin Biol. Dec 2014; 21(6): 303-8.

[11] Nambei WS, Rawago-Mandjiza D, Gbangbangai E. Seroepidemiology of HIV, syphilis and hepatitis B and C viruses among blood donors in Bangui, Central African Republic. Med Sante Trop. 1 May 2016; 26(2): 192-8.

[12] Birhaneselassie M. Prevalence of Transfusion-Transmissible Infections in Donors to an Ethiopian Blood Bank Between 2009 and 2013 and Donation Factors That Would Improve the Safety of the Blood Supply in Underdeveloped Countries. Lab Med. May 2016; 47(2): 134-9.

[13] Allain JP, Sibinga CT. Family donors are critical and legitimate in developing countries. Asian J Transfus Sci. JanJun 2016; 10(1): 5-11.

[14] WHO, Status of Blood Safety in the WHO African Region; report of the 2010 survey. Brazzaville, Republic of Congo. World Health Organization 2014.

[15] Bloch EM, Vermeulen M. Murphy E. Blood Transfusion Safety in Africa: A Literature Review of Infectious Disease and Organizational Challenges. Transfusion Medicine Reviews. 2012; 26(2): 164-180.

[16] Allain JP, Sibinga CT. Family donors are critical and legitimate in developing countries. Asian J Transfus Sci. JanJun 2016; 10(1): 5-11.

[17] Asenso-Mensah K, Achina G, Appiah R, Owusu-Ofori S, Allain JP. Can family or replacement blood donors become regular volunteer donors? Transfusion. Mar 2014; 54(3 Pt 2): 797-804.

[18] Misje AH, Bosnes V, Heier HE. Gender differences in presentation rates, deferrals and return behaviour among Norwegian blood donors. Vox Sang. Apr 2010; 98(3 Pt 1): e241-8.

[19] Prados Madrona D, Fernández Herrera MD, Prados Jiménez D, Gómez Giraldo S, Robles Campos R. Women as whole blood donors: offers, donations and deferrals in the province of Huelva, south-western Spain. Blood Transfus. Jan 2014; 12 Suppl 1: s11-20.

[20] Tavakol N, Kheiri S, Sedehi M. Analysis of the Factors Affecting the Interval between Blood Donations Using LogNormal Hazard Model with Gamma Correlated Frailties. J Res Health Sci. 2016; Spring; 16(2): 76-80.

[21] Thompson WW. Blood donation behavior of Hispanics in the lower Rio Grande Valley. Transfusion. Apr 1993; 33(4): 333-5.

[22] Diarra A, Kouriba B, Baby M, Murphy E, Lefrere JJ. HIV, HCV, HBV and syphilis rate of positive donations among blood donations in Mali: lower rates among volunteer blood donors. Transfus Clin Biol. Nov-Dec 2009; 16(5-6): 444-7.

[23] Koné MC, Sidibé ET, Mallé KK, Beye SA, Lurton G, Dao S, Diarra MT, Dao S. Seroprevalence of human immunodeficiency virus, hepatitis B virus and hepatitis C virus among blood donors in Segou, Mali. Med Sante Trop. Jan-Mar 2012; 22(1): 97-8.

[24] Mayaki Z, Dardenne N, Kabo R, Moutschen M, Sondag D, Albert A, Gérard C. Seroprevalence of infectious markers among blood donors in Niamey (Niger). Rev Epidemiol Sante Publique. Jun 2013; 61(3): 233-40.

[25] Buseri FI, Muhibi MA, Jeremiah ZA. Sero-epidemiology of transfusion-transmissible infectious diseases among blood donors in Osogbo, south-west Nigeria. Blood Transfus. Oct 2009; 7(4): 293-9. 
[26] Ankouane F, Noah Noah D, Atangana MM, Kamgaing Simo R, Guekam PR, Biwolé Sida M. Seroprevalence of hepatitis $B$ and $C$ viruses, HIV-1/2 and syphilis among blood donors in the Yaoundé Central Hospital in the centre region of Cameroon. Transfus Clin Biol. May 2016; 23(2): 72-7.

[27] Offergeld R, Ritter S, Hamouda O. HIV, HCV, HBV and syphilis surveillance among blood donors in Germany 20082010. Bundesgesundheitsblatt Gesundheitsforschung Gesundheitsschutz. Aug 2012; 55(8): 907-13.

[28] Sommese L, Iannone C, Cacciatore F, De Iorio G, Napoli C. Comparison between screening and confirmatory serological assays in blood donors in a region of South Italy. J Clin Lab Anal. May 2014; 28(3): 198-203.

[29] Sehgal S, Shaiji PS, Brar RK. Seroprevalence and Trends of Transfusion Transmissible Infections in Blood Donors in Andaman and Nicobar Islands- An Institutional Retrospective Study. J Clin Diagn Res. Apr 2017; 11(4): EC21EC24.

[30] Mole S, Onana E, Biholong D. HIV and risk factors for the blood donors at the central hospital of Yaounde, Cameroon. Bull Soc Pathol Exot. Aug 2011; 104(3): 226-31.

[31] Tounkara A, Diakite M, Noumsi GT, Sarro YD, Siddiqui S, Parta M. Retrospective surveillance of HIV prevalence in blood donors can help in the selection of the best social group for blood donation in Mali. Transfus Med. Oct 2009; 19(5): 252-9.

\section{Author's short Biography}

Dr. Modibo COULIBALY is a Pharmacist and Clinical Laboratory Scientist. He is the head of the
Biomedical Laboratory at Hôpital Sominé DOLO de Mopti. He is also a research fellow in clinical
biochemistry at the Centre National de Recherche Scientifique et Technologique of Mali
(CNRST/Mali). His areas of interest are clinical biology, cardiovascular and metabolic diseases.

